\title{
SONDERFORSCHUNGSBEREICH 504
}

\section{Rationalitätskonzepte, Entscheidungsverhalten und ökonomische Modellierung}

\begin{tabular}{|c|} 
No. 04-45 \\
Bank Capital, Liquidity and Systemic Risk \\
Jürgen Eichberger* \\
and Martin Summer**
\end{tabular}

November 2004

We would like to thank Eva Terberger for helpful discussions in the early stages of this paper. We also thank Amil Dasgupta, Douglas Gale, Charles Goodhart, Hyun Song Shin, Jan Wenzelburger as well as conference and workshop participants in Berlin, Mannheim, M?unster Stockholm and Madrid for their comments. Martin Summer thanks the Bank of England and the London School of Economics for their hospitality while working on this paper. Any views expressed in the paper are strictly the views of the authors and do not necessarily coincide with the views of OeNB.

*Sonderforschungsbereich 504, email: juergen.eichberger@awi.uni-heidelberg.de

** Oesterreichische Nationalbank, email:

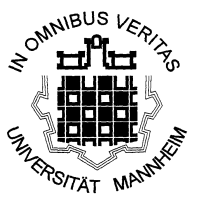

Universität Mannheim

L 13,15

68131 Mannheim 


\title{
Bank Capital, Liquidity and Systemic Risk *
}

\author{
Jürgen Eichberger \\ University of Heidelberg
}

\author{
Martin Summer \\ Oesterreichische Nationalbank ${ }^{\dagger}$
}

\begin{abstract}
We analyze the impact of capital adequacy regulation on bank insolvency and aggregate investment. We develop a model of the banking system that is characterized by the interaction of many heterogeneous banks with the real sector, interbank credit relations as a consequence of bank liquidity management and an insolvency mechanism. This allows us to study the impact of capital adequacy regulation on systemic risk. In particular we can analyze the impact of regulation on contagious defaults arising from mutual credit relations. We show that the impact of capital adequacy on systemic stability is ambiguous and that systemic risk might actually increase as a consequence of imposing capital constraints on banks. Furthermore we analyze the indirect consequences of capital adequacy regulation that are transmitted to the real economy by their impact on equilibrium interbank rates and thus the opportunity costs of liquidity within the banking system.
\end{abstract}

\section{JEL-Classification Numbers: G21, G28, E44.}

\section{Introduction}

The policy discussion about banking regulation during the past two decades has been mainly concerned with capital adequacy. This focus was reinforced by the refinement

*Aknowledgements: We would like to thank Eva Terberger for helpful discussions in the early stages of this paper. We also thank Amil Dasgupta, Douglas Gale, Charles Goodhart, Hyun Song Shin, Jan Wenzelburger as well as conference and workshop participants in Berlin, Mannheim, Münster Stockholm and Madrid for their comments. Martin Summer thanks the Bank of England and the London School of Economics for their hospitality while working on this paper. Any views expressed in the paper are strictly the views of the authors and do not necessarily coincide with the views of OeNB.

†E-mail: Eichberger: juergen.eichberger@awi.uni-heidelberg.de; Summer: martin.summer@oenb.co.at 
of existing capital adequacy rules by the Basel Committee which forms the core of the regulatory reform known as "Basel II". In the debate about how to reform the existing framework questions concerning the general rationale of capital adequacy have been moved to the background. Moreover, whether such regulation can actually serve as a safeguard against financial crises - as it is often claimed in policy debates - has perhaps received insufficient attention. In favor of capital adequacy the literature advances two different arguments. On the one hand, capital adequacy is seen as an instrument limiting excessive risk taking of bank owners with limited liability and, thus, promoting optimal risk sharing between bank owners and depositors. On the other hand, capital adequacy regulation is often viewed as a buffer against insolvency crises, limiting the costs of financial distress by reducing the probability of insolvency of banks. Irrespective of the viewpoint taken, one usually finds a general reference to financial stability, suggesting that capital adequacy regulation provides a safeguard against systemic crises. The mechanism linking capital adequacy and systemic risk remains however usually unexplained. In this paper we provide a new framework in which the dependence between the buffer stock view of bank capital and systemic risk can be discussed more precisely. In particular we discuss the impact of capital adequacy on default probabilities arising from domino effects of insolvency transmitted through the interbank market.

Given the extensive literature on capital adequacy regulation, it may appear surprising that the impact of this particular regulatory policy on financial stability has not been analyzed more rigorously. Yet most models in the banking literature deal with a single bank's decision problem and the incentives of the different claim holders of the bank, in particular of bank owners and managers. With a single bank it is clearly impossible to describe the two major sources of systemic risk: correlated portfolio positions in the banking system and domino-effects in consequence of interbank exposures. Apart from an early paper by Hellwig and Blum (1995) there are few attempts in the literature on capital regulation to move from a single-bank to a system perspective. While financial stability and the macroeconomic consequences of solvency regulation are studied in Gorton and Whinton (1995), Gersbach and Wenzelburger (2002), the issue of how financial linkages transmit, and possibly amplify, financial crises has received relatively little attention (see however the papers by Allen and Gale (2000), Goodhart, Sunidrand, and Tsomocos (2003) and Cifuentes, Ferucci, and Shin (2003)).

This paper provides a framework that can shed light on this issue. In particular, we analyze the impact of capital adequacy requirements on default probabilities and the systemic risk from domino effects. We consider a simple one-period model with heterogeneous banks that finance risky loans of enterprises. When banks make their loan decisions, their deposits and equity are already determined. If banks want to increase loans beyond what they can finance from their deposits and equity, they can obtain additional liquidity from banks with a surplus of funds through a competitive interbank market. The competitive interbank rate determines both the opportunity costs of a bank's loans to firms and the credit positions among banks participating in the interbank market. 
Shocks to a bank's corporate loan portfolio may cause insolvencies. The resulting shortfalls of payments are settled in a clearing system that establishes ex-post consistency of all financial claims. This model captures two sources of systemic risk, a direct exposure of banks to common risk factors and the indirect exposure to credit risk in the interbank market.

We assume that banks are subject to a capital adequacy rule in order to study how this regulation affects the interbank rate and default probabilities. We find that the consequences of capital adequacy regulation for systemic stability are not clear cut. Considering also the indirect effects of capital adequacy regulation, we can show that a capital adequacy regime, while boosting the capital buffer of individual banks, may increase the risk of contagious insolvencies in the banking system as a whole.

\section{A Model of the Banking System}

Consider a set $\mathcal{J}=\{1, \ldots, J\}$ of banks operating over one period which starts at $t=0$ and ends at $t=1$. Each bank has a group of firms as customers. Firms in each group depend on their home bank for finance of their investment projects. Hence, each firm belongs to the customer base of one particular bank. Firms within the customer group of a bank are characterized by a continuum of different productivities $q \in[0, M]^{1}$, ranging from the lowest productivity $q=0$ to maximal productivity $q=M$. While the productivity parameter is private knowledge of the firms, it is common knowledge that productivities are uniformly distributed on $[0, M]$. Investment projects of firms require a fixed input of 1 unit of capital at the beginning of the period and yield a risky payoff at the end of the period. The payoff of a firm with productivity $q$ is described by the function $f\left(s_{j}, A, q\right)=s_{j} \cdot A \cdot q$ where $A>0$ denotes an aggregate productivity parameter for the firm group and $s_{j}$ a random variable indicating group-specific success or failure of projects. We assume that $s_{j} \in\{0,1\}$ for all $j \in \mathcal{J}$ and that the probability of success is given by $\operatorname{Pr}(s=1)=\rho$ with $\rho \in(0,1)$. Firms within a group are distinguished only by their productivity parameter $q$. In particular, we do not model firm-specific shocks. All firms in a bank's customer group suffer the same shock $s_{j}$. We view $s_{j}$ as a shock to the bank's loan portfolio. Firms have limited liability and for each firm the opportunity costs of not undertaking a project are normalized to zero.

We assume that only those firms take a loan that expect a strictly positive profit at the loan interest rate $R_{j}$ which its bank charges. A firm of productivity $q$ facing a loan interest rate $R_{j}$ will choose to take a loan if its expected profit,

$$
\Pi\left(R_{j}, q\right):=\rho \max \left[f(1, A, q)-R_{j}, 0\right],
$$

strictly exceeds the payoff from the outside option of 0. Since expected profit is strictly

\footnotetext{
${ }^{1}$ This setup builds on work by Gersbach and Wenzelburger (2002).
} 
increasing in $q$ in each customer group we have a critical $q^{*}$ such that all firms with a strictly larger $q$ take the loan and all others take the outside option. Thus we get an aggregate loan demand function

$$
Q\left(R_{j}\right):=M-q^{*}\left(R_{j}\right)
$$

for each customer group.

Each bank has an initial equity $e_{0 j} \in \mathbb{R}_{++} \cdot{ }^{2}$ The initial equity results from the settlement of past loans after shocks of the previous period have been realized, deposits have been paid and interbank claims have been cleared. Each bank also has a stock of deposits $d_{0 j}$ that require a (gross) interest rate $D$ in period $t=1$. The equity $e_{0 j}$ is positive because banks with negative equity are insolvent and exit the banking system.

Banks maximize expected profits from loans to their firm group. They monopolistically quote a loan interest rate $R_{j}$ and supply loans to satisfy the loan demand according to their loan demand functions. The market power of banks results from the client-specific relationship with its firm group. Banks can use their funds $\left(e_{0 j}+d_{0 j}\right)$ to finance loans. If they need additional funds they enter a competitive interbank market where they can raise them at a gross interest rate $I$ from other banks that don't lend all of their initial wealth to firms in their own group. The interbank market allows banks to competitively exchange funds at $t=0$. Define $l_{j}^{+}:=\max \left\{l_{j}, 0\right\}$ and $l^{-}:=-\min \left\{l_{j}, 0\right\}$ to denote long and short interbank positions. When choosing their loan interest rate $R_{j}$ and their interbank positions $l_{j}^{+}, l_{j}^{-}$banks are subject to the following budget constraint:

$$
\mathcal{B}_{j}\left(e_{0 j}, d_{0 j}\right):=\left\{\left(R_{j}, l_{j}\right) \in \mathbb{R}_{+} \times \mathbb{R} \mid Q\left(R_{j}\right)+l_{j}^{+}-l_{j}^{-} \leq e_{0 j}+d_{0 j}\right\} .
$$

Shocks to the technologies of firms, and hence to the $J$ banks whose customers they are, will induce one of $2^{J}$ states $s=\left(s_{1}, \ldots, s_{J}\right) \in \mathcal{S}:=\{0,1\}^{J}$, where $s_{j}$ indicates whether bank $j$ has a positive return on its loans, $s_{j}=1$, or not, $s_{j}=0$. We denote the probability of a state $s$ by $\pi(s)$.

If a bank finances its loan portfolio with an interbank loan and if the customers of this bank suffer a negative shock, then the realized value of the bank is negative since $-I \cdot l_{j}^{-}<0$. The bank is insolvent and some banks with positive positions in the interbank market cannot realize the full return on their interbank investment $l_{j}^{+}$. A clearing system will redistribute such losses among the banks participating in the interbank market. If in a state $s \in \mathcal{S}$ some banks fail, the return rate of the lending banks will be less than $I$. Denote by $\delta(s) \in[0,1]$ the discount on the contracted interest rate $I$ which a lending bank suffers, then lending banks receive an actual return rate of $\delta(s) \cdot I$ on their interbank loans. Below, we will assume that all lending banks are treated equally by the clearing system. Hence, the discount quota $\delta(s)$ will be the same for all lending banks.

\footnotetext{
${ }^{2}$ Since each firm group finances its projects by loans from only one bank we can choose the same index for banks as for firm groups.
} 


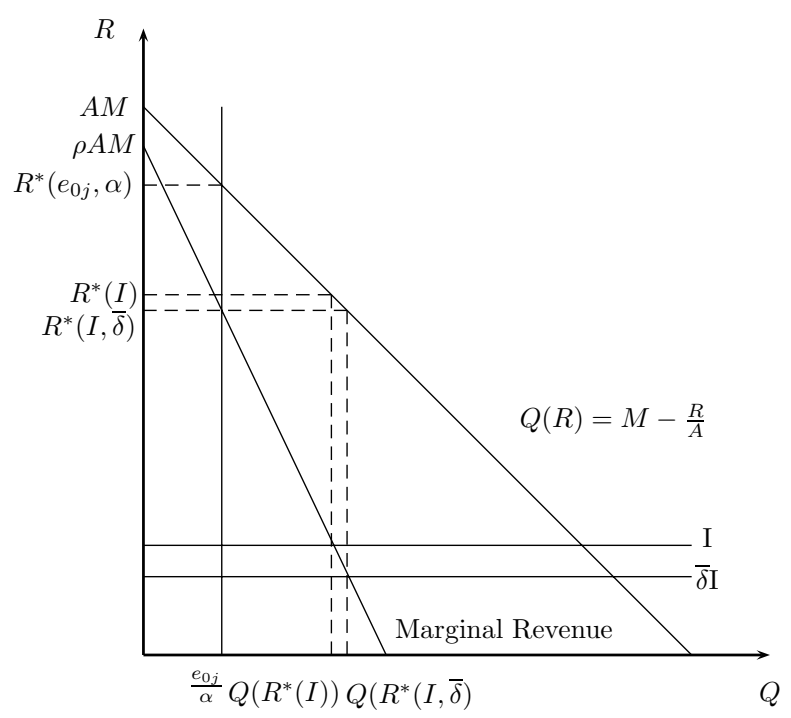

Figure 1. The optimal bank decision with capital adequacy.

The expected profit of a bank $V\left(R_{j}, l_{j}^{-}, l_{j}^{+} \mid I^{*}, \bar{\delta}^{*}, D\right)$ is given by

$$
\rho \cdot R_{j} \cdot Q\left(R_{j}\right)+\bar{\delta} \cdot I \cdot l_{j}^{+}-I \cdot l_{j}^{-}-D \cdot d_{0 j}
$$

where $\bar{\delta}:=\sum_{s \in S} \pi(s) \cdot \delta(s)$ denotes the average discount across states on the contracted loan interest rate $I$.

Capital adequacy means that banks have to obey additional constraints. The regulation determines the percentage $\alpha$ of the loan portfolio that has to be covered by equity ${ }^{3}$ :

$$
\alpha \cdot Q_{j}\left(R_{j}\right) \leq e_{0 j}
$$

Maximizing expected profit subject to the budget constraint (3) and the capital adequacy constraint (5), one obtains the optimal bank decision. Figure 1 illustrates the optimal bank decision graphically. If the capital adequacy constraint does not bind, the bank's problem looks very much like a standard monopoly problem with the exception that the marginal costs of lending funds are endogenously determined by the interbank market (the rate $I$ ) and expectations of shortfall of interbank investments (the discount factor $\delta$ ). If the capital adequacy constraint is binding a bank has to restrict its supply of credit to fulfill the constraint. A formal description of the optimal bank decision is given in Eichberger and Summer (2004) proposition 4.

\footnotetext{
${ }^{3}$ We would like to acknowledge discussions with Eva Terberger which helped us shape the capital adequacy constraint.
} 
In each period, banks may borrow or lend in the interbank market. At the end of the period $t=1$, when shocks $s \in \mathcal{S}$ are realized, situations can arise where some banks suffer a negative shock, $s_{j}=0$. These banks are not able to fulfill their liabilities both towards the interbank market and their depositors. Furthermore the failure of a counterparty in the interbank market can even lead to the insolvency of banks who get the full return on their loan portfolio.

We assume that debts are settled through a centralized clearing system that makes claims ex-post consistent by redistributing the value of insolvent institutions among its creditors. Insolvent banks exit the banking system. Banks that have invested in the interbank market have a claim on the clearing house. Banks that raise funds from the interbank market have a liability to the clearing house. The clearing house has no independent income or reserves. Hence, each insolvency of a bank implies that the clearing house can only partially fulfill its obligations. As a result of insolvencies the value of these lenders' claims must be reduced. We assume that banks with a claim on the clearing house get payed proportionally to their liabilities. Therefore shortfalls in the interbank market can lead to second round effects of insolvencies through the network of interbank credits. A formal description of the clearing problem can be found in Eichberger and Summer $(2004) \cdot{ }^{4}$

\section{Equilibrium}

An equilibrium of this model is defined by a profile of optimal bank loan rates $R_{j}^{*}$, loan demands $Q\left(R_{j}^{*}\right)$ induced by the critical productivity threshold $q_{j}^{*}$, interbank positions $l_{j}^{*}$, and a market clearing interbank rate $I^{*}$ such that all banks maximize their expected profit and the interbank market clears. In addition, we require expectations of firms about the

repayment rate on interbank loans $\bar{\delta}$ to be consistent with the actual repayment rates realized by the clearing house. Formally, we state the following definition:

\section{Definition 1 Equilibrium.}

An equilibrium is a list $\left(\left(R_{1}^{*}, \ldots, R_{J}^{*}\right), I^{*}\right)$ of interest rates, a list $\left(\left(l_{j}^{*}, q_{j}^{*}\right)_{j \in \mathcal{J}},\right)$ of interbank positions, loan demands and repayment quotas $\left(\delta^{*}(s)\right)_{s \in \mathcal{S}}$ such that:

1. For each $j \in \mathcal{J}$

$$
q_{j}^{*}=\max \left\{q_{j} \in[0, M] \mid \Pi\left(R_{j}^{*}, q_{j}\right)=0\right\}
$$

2. For each $j \in \mathcal{J}$

$$
\left(R_{j}^{*}, l_{j}^{*}\right) \underset{\left(R_{j}, l_{j}\right) \in \mathcal{B}_{j}\left(e_{0 j}, d_{0 j}\right)}{\operatorname{argmax}} V\left(R_{j}, l_{j}^{-}, l_{j}^{+} \mid I^{*}, \bar{\delta}^{*}, D\right) .
$$

\footnotetext{
${ }^{4}$ Our clearing house is a special case of the clearing system analyzed by Eisenberg and Noe (2001).
} 
3. The interbank market clears,

$$
\sum_{j \in \mathcal{J}}\left(l_{j}^{+*}-l_{j}^{*-}\right)=0 .
$$

4. Expectations about repayment are rational,

$$
\bar{\delta}^{*}=\sum_{s \in \mathcal{S}} \pi(s) \cdot \delta^{*}(s)
$$

In equilibrium banks choose their loan policies and their interbank position optimally. Simultaneously, firms decide on their optimal investment behavior. Finally the interbank rate has to be set such that the interbank positions of the banks clear. Notice that, in equilibrium, expectations about the repayment ratio from the interbank market are correct. Under weak assumptions on the distribution of initial funds existence of equilibrium can be guaranteed. ${ }^{5}$ The equilibrium allocation and rates enter the clearing system. Once shocks have been realized, they determine the value of the banks, which is their equity in period $t=1$. The equity positions $e_{1}$ open a new stage of bank activities and interbank transactions.

\section{Capital Adequacy and Systemic Risk}

What role does capital adequacy play for equilibrium? The explicit description of heterogeneous banks and the interbank linkages allow us to analyze direct and indirect consequences of the regulatory policy.

The immediate impact of a capital adequacy constraint can be deduced from an analysis of the optimal bank decision. If the capital adequacy constraint of firm $j$ binds, then the interest rate for this bank's loans will increase, its loans to firms will decrease, and its interbank position will also increase with $\alpha$. This effect is straightforward (for a formal analysis see Eichberger and Summer (2004)). These effects capture the logic of the regulation. Capital adequacy constraints reduce exposure to the risk of the regulated asset. Notice that, for a binding constraint, these effects depend neither on the interbank refinance rate $I$ nor on the expected return quota $\bar{\delta}$.

A capital adequacy constraint limits the amount of bank capital invested in a particular asset. Since it does not specify an alternative investment, it is neither a reserve requirement nor a buffer guaranteeing that the bank can satisfy its creditors from the returns on its equity. The degree of protection achieved with a capital adequacy constraint depends crucially on the returns which banks can earn on other investments. Returns on

\footnotetext{
${ }^{5}$ For a formal statement of these conditions and a proff of existence see Eichberger and Summer $(2004))$.
} 
other assets will be affected by the investment decisions of banks in response to a binding capital adequacy constraint. Systemic effects on the returns of other assets are often neglected, when the effectiveness of regulation is assessed. Such systemic effects may lead us to reconsider the aptitude of capital adequacy regulation as a tool for improvement of a banks' risk exposure.

In our model, the only alternative investment opportunity of banks is the interbank market. A capital-adequacy constrained bank will increase its position in the interbank market, i.e., increase its lending in this market or decrease its borrowing from it. Though the interbank market is not subject to direct risk from shocks, it may be indirectly affected if banks fail in response to bank-specific shocks.

Secondary effects of changed positions in the interbank market following capital adequacy regulation need to be studied. These secondary effects are summarized in the following proposition. ${ }^{6}$

\section{Capital Adequacy and the Interbank Market}

Consider an equilibrium with binding capital adequacy constraints for some firms. If the capital adequacy ratio $\alpha$ is increased, then the interbank interest rate $I^{*}(\alpha)$ falls. Formally, $\alpha^{\prime}>\alpha$ implies

$$
I^{*}\left(\alpha^{\prime}\right)<I^{*}(\alpha)
$$

The consequences capital adequacy regulation for the risk exposure of the banking system as a whole are not clear. The interbank market allows banks to shift risk from banks with little equity to banks with more equity. Whether this reallocation of funds among banks increases the financial stability of the banking system depends on the distribution of deposits. The following example illustrates this point.

\section{Example 1 Capital Adequacy can increase Systemic Risk}

Assume that we have two banks. Let $M=2, A=1, \rho=0.979$ and $\alpha=0.08$. The initial equity and deposit positions are given by $\left(e_{01}, d_{01}\right)=(0.024,0.462)$ and $\left(e_{02}, d_{02}\right)=$ $(0.1,0.2)$. Let the deposit rate be given by $D=1.3$ and assume that there is no capital adequacy constraint. The following table contains the equilibrium values for the case without capital adequacy regulation.

$\begin{array}{ll}\text { Bank 1: } & \left(R_{1}^{*}(0), Q_{1}^{*}(0), l_{1}^{*}(0)\right)=(1.600,0.4,0.087), \\ \text { Bank 2: } & \left(R_{2}^{*}(0), Q_{2}^{*}(0), l_{2}^{*}(0)\right)=(1.613,0.387,-0.087), \\ \text { Interbank rate } & I^{*}(0)=1.20, \\ \text { Expected default rate: } & \bar{\delta}^{*}(0)=0.979 .\end{array}$

\footnotetext{
${ }^{6}$ For a proof see Eichberger and Summer (2004).
} 
It is easy to check that, at these equilibrium values, bank 1 would not fulfill its capital adequacy constraint.

If a bank's loan portfolio suffers a shock the bank will have no funds to repay its loans. Bank 2 who is borrowing from the interbank market will fail in states $(1,0)$ and $(0,0)$ and pay back its full loan plus interest in the other states. The settlement payments $p_{i}(s)$ are listed in the following table.

\begin{tabular}{c|l|l|l|}
$s=\left(s_{1}, s_{2}\right)$ & $\pi(s)$ & $p_{1}(s)$ & $p_{2}(s)$ \\
\hline$(1,1)$ & 0.960 & 0 & 0.104 \\
\hline$(1,0)$ & 0.019 & 0 & 0 \\
\hline$(0,1)$ & 0.019 & 0 & 0.104 \\
\hline$(0,0)$ & 0.002 & 0 & 0 \\
\hline
\end{tabular}

In states $(1,1)$ and $(0,1)$, the repayment ratio is $\delta(1,1)=\delta(0,1)=1$, while it is zero in the other states. Hence,

$$
\bar{\delta}^{*}=\sum_{s \in S} \pi(s)=0.979
$$

as the banks expected when making their decisions.

If we look at the four states of the system we see that in case of both firm groups being successful both banks will be able to honor their promises and to pay off their depositors. If both firm groups are in a bad state, clearly both banks fail. Note that bank 1 earns enough from its loan portfolio, $R^{*}(0) \cdot Q^{*}(0)=0.64$ in order to repay depositors, $D \cdot d_{01}=0.6$, even if bank 2 were to default on its interbank promises. Although its profits would decline sharply as a consequence of such a bank failure, bank 1 would not become insolvent. On the other hand, if the loan portfolio of bank 1 fails, it will become insolvent even if bank 2 fully honors all its interbank promises. Hence, without a capital adequacy constraint, there are no contagious defaults. Banks fail only in direct consequence of their loan portfolio's risk.

Consider now the case where the capital adequacy regime becomes effective. In this case bank 1 hits its capital constraint. The equilibrium values for $\alpha=0.08$ are listed in the following table.

$$
\begin{array}{ll}
\text { Bank 1: } & \left(R_{1}^{*}(\alpha), Q_{1}^{*}(\alpha), l_{1}^{*}(\alpha)\right)=(1.7,0.3,0.186), \\
\text { Bank 2: } & \left(R_{2}^{*}(\alpha), Q_{2}^{*}(\alpha), l_{2}^{*}(\alpha)\right)=(1.514,0.486,-0.186), \\
\text { Interbank rate } & I^{*}(\alpha)=1.00, \\
\text { Expected default rate: } & \bar{\delta}^{*}(\alpha)=0.979 .
\end{array}
$$

The expected default rate remains unchanged, because $p_{2}(s)$ will again equal 1 , in those states where bank 2's loan portfolio pays off, and 0 in the other states. 
While bank 1 was able to absorb the failure of its interbank counterparty in the regime without capital adequacy $(\alpha=0)$, it falls victim of a contagion effect in the new regime with $\alpha=0.08$. At this capital adequacy rate $R^{*}(\alpha) \cdot Q^{*}(\alpha)=0.51$ do not suffice to pay back its depositors, $D \cdot d_{01}=0.6$. The probability of observing this domino effect is $\pi(1,0)=0.019$ with an capital adequacy constraints, while it is nil without such regulation. Hence, capital adequacy increases systemic risk.

This example illustrates the mechanism of risk transmission through the interbank market. Capital adequacy constraints set bank funds free for loans to other banks. These extra funds lower the interest rate $I$, from $I(0)=1.2$ to $I(\alpha)=1$. The cheaper funds of the interbank market induce unconstrained banks to lend more to their group of firms, $Q_{2}^{*}(\alpha)=0.486>0.387=Q_{2}^{*}(0)$. As a consequence, a failure of bank 2 will create a greater loss for the banking system. Bank 1 loses more funds in the interbank market and, because of the capital adequacy constraint, it receives less returns from lending to its group of firms. Thus, it can no longer honor its commitments to its depositors.

Systemic risk works through the interbank market which allows banks to exchange surplus funds. Constraining lending activities of banks by a capital adequacy constraint redirects funds to other banks whose constraints are not binding. This mechanism increases the risk exposure of these banks. Capital adequacy regulation encourages lending of banks with high equity at the expense of banks with little equity. If there is no positive correlation between the amount of equity a bank holds and the quality of its loan portfolio, then the risk from such rechanneling of funds may increase systemic risk.

How robust are the insight given by our example? Whether one considers the systemic risk displayed in our model as a relevant feature of actual banking systems depends on the acceptability of the assumptions of the model. There are a number of assumptions which serve only the purpose of a simpler exposition. For example, it would be possible to consider differing characteristics of the banks' groups of firms. One could also allow firms to seek funds from other banks at some extra cost or by selling some debt, as long as banks retain some comparative advantage as loan providers for their own groups of firms. In fact, empirical studies suggest that firms cannot easily substitute other sources of finance for bank credit because of asymmetric information (Freixas and Rochet (1997)) and credit constraints (Hoshi, Kahiap, and Scharfstein (1991)). Moreover, in many countries bank finance is the most important sources of external finance for firms.

We have refrained from generalizing firms' behavior, because it is inessential for the point of systemic risk through the interbank market which forms the core of our paper. The effect of capital adequacy regulation in this paper rests on two features of our model which we wish to discuss in more detail.

1. Other assets. Would systemic risk via the interbank transactions remain as important, if banks had other investment opportunities than loans to firms or interbank lending? In particular, if banks could hold a safe asset as reserves for losses. We believe that the answer to this question is yes. 
If there was a completely safe asset which banks could hold as reserve, it would necessarily have to pay a lower return as lending in the interbank market. With risk-neutral banks such an investment possibility would be dominated by lending to other banks. If banks were risk-averse, banks may decide to hold some fraction of their funds in the safe asset with inferior return. This fraction would depend on the degree of risk aversion of the banks. Even with risk aversion, however, banks would increase lending in the interbank market, if capital adequacy regulation would divert funds to this market and lower the interbank interest rate. A safe reserve asset together with risk aversion of the banks would moderate the redirection of funds through the interbank market. Yet, there is no reason to believe that it would destroy the interbank market.

Regulators may try to overcome the redirection of funds via the interbank market by imposing capital adequacy constraints also on interbank positions. By a capital adequacy constraint on both loans to firms and lending to the interbank market, they may force banks to invest funds that cannot go into their loan portfolio or the interbank market, in the safe asset. In this case, capital adequacy regulation would work like a reserve requirement. If regulation falls short of enforcing 100-percent reserve holdings for risky loans to firms, it would still be open to the systemic risk described in the previous section. Banks that would be constrained in their lending to firms, but not in their lending to the interbank market, would redirect their funds to the interbank market because of the higher returns. The additional loan supply in the interbank market lowers the interest rate and induces more lending to banks that do not face a binding capital adequacy constraint for their lending to firms. Thus, systemic risk will increase again.

2. New equity. A second important assumption is the fixed amount of bank equity. One could imagine that, confronted with capital adequacy regulation, a bank would issue new equity in order to avoid being forced to cut back loans to its firms. Legal restrictions, which for a number of reasons make issuing new equity a complicated business in many countries, often rule out this option. Yet, even if there is no such impediment, it is questionable if such a policy would succeed. Issuing new equity tends to lower the equity value. If one interprets low equity values as a result of depressed economic conditions, then issuing new equity may suffer from adverse signaling effects (Greenbaum and Thakor (1995)). Hence, working with a fixed equity for banks appears to be reasonable assumption.

\section{Conclusions}

The analysis of the economic consequences of capital adequacy regulation for the financial stability of a system of banks requires a framework, which allows for heterogeneous banks, mutual credit relations and potential defaults. We have presented a simple model with these features. Our analysis shows that the effects of capital adequacy regulation for

financial stability are ambiguous. While capital constraints limit credit exposures of 
banks with a weak equity base, the risk exposure of other institutions in the system may increase through higher risk from interbank exposures. The probability of contagious default can rise. Capital constraints have indirect effects on the allocation of aggregate funds among firms in the economy. It is not clear whether a capital adequacy regime will lead to a lower risk exposure of the banking system as a whole.

If regulation aims at the risk allocation in the entire banking system, then it has to depart from concentrating on individual bank balance sheets. A regulator who wants to use capital adequacy regulation to influence the risk exposure of the banking system finds himself in a similar position as a portfolio manager. Individual positions in a portfolio have to be judged on the basis of their contribution to the overall portfolio risk and cannot be analyzed in isolation. A system approach to banking regulation is in the beginning. ${ }^{7}$ We hope that our model provides a useful starting point for analyzing some of the problems that arise with the regulatory control of systemic risk.

\footnotetext{
${ }^{7}$ Some methodological and empirical work has been done in this sense: See Lehar (2002), Elsinger, Lehar, and Summer (2002)
} 


\section{References}

Allen, Franklin, and Douglas Gale, 2000, Financial Contagion, Journal of Political Economy 108, 1-34.

Cifuentes, Rodrigo, Gianluigi Ferucci, and Hyun Song Shin, 2003, Liquidity Risk and Contagion, Mimeo.

Eichberger, Jürgen, and Martin Summer, 2004, Bank Capital, Liquidity and Systemic Risk, OeNB Working Paper Nr. 87.

Eisenberg, Larry, and Thomas Noe, 2001, Systemic Risk in Financial Systems, Management Science 47, 236-249.

Elsinger, Helmut, Alfred Lehar, and Martin Summer, 2002, Risk Assessment for Banking Systems, Oesterreichsiche Nationalbank, Working Paper Nr. 79.

Freixas, Xavier, and Jean-Charles Rochet, 1997, The Microeconomics of Banking. (MIT Press) first edn.

Gersbach, Hans, and Jan Wenzelburger, 2002, The Workout of Banking Crises: A Macroeconomic Perspective, University of Bielefeld, Working Paper.

Goodhart, Charles, Ponjanart Sunidrand, and Dimitrios Tsomocos, 2003, A Model of Financial Fragility, Mimeo.

Gorton, Gary, and Andrew Whinton, 1995, Bank Capital Rquirements in a General Equilibrium Framework, NBER Working Paper 5244 47.

Greenbaum, S., and A. Thakor, 1995, Contemporary Financial Intermediation. (Dryden Press) first edn.

Hellwig, Martin, and Jürg Blum, 1995, Do Capital Requirements Reduce Risk Taking in Banking?, European Economic Review 39, 755-771.

Hoshi, T., A. Kahiap, and D. Scharfstein, 1991, Corporate Structure, Liquidity and Investment: Evidence from Japanese Industrial Groups, Quarterly Journal of Economics $106,236-247$.

Lehar, Alfred, 2002, Implementing a Portfolio Perspective in Banking Regulation, University of Vienna, Mimeo. 


\begin{tabular}{|c|c|c|c|c|c|}
\hline$\overline{\mathrm{Nr} .}$ & 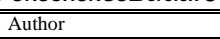 & Title & Nr. & Author & 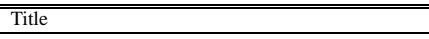 \\
\hline $04-43$ & $\begin{array}{l}\text { Fabian Bornhorst } \\
\text { Andrea Ichino } \\
\text { Oliver Kirchkamp } \\
\text { Karl H. Schlag } \\
\text { Eyal Winter }\end{array}$ & $\begin{array}{l}\text { How do People Play a Repeated Trust Game? } \\
\text { Experimental Evidence }\end{array}$ & $04-32$ & $\begin{array}{l}\text { Christopher Koch } \\
\text { Oliver Kirchkamp } \\
\text { J. Philipp Reiß }\end{array}$ & $\begin{array}{l}\text { Haftungserleichterungen bei der Offenlegung von } \\
\text { Zukunftsinformationen in den USA } \\
\text { The overbidding-myth and the underbidding-bias in } \\
\text { first-price auctions }\end{array}$ \\
\hline $04-42$ & Martin Hellwig & $\begin{array}{l}\text { Optimal Income Taxation, Public-Goods Provision } \\
\text { and Public-Sector Pricing: A Contribution to the } \\
\text { Foundations of Public Economics }\end{array}$ & $04-31$ & $\begin{array}{l}\text { Alexander Ludwig } \\
\text { Alexander Zimper }\end{array}$ & $\begin{array}{l}\text { Investment Behavior under Ambiguity: The Case of } \\
\text { Pessimistic Decision Makers }\end{array}$ \\
\hline $04-41$ & Thomas Gschwend & $\begin{array}{l}\text { Comparative Politics of Strategic Voting: A } \\
\text { Hierarchy of Electoral Systems }\end{array}$ & $04-30$ & Volker Stocké & $\begin{array}{l}\text { Attitudes Toward Surveys, Attitude Accessibility } \\
\text { and the Effect on Respondentsí Susceptibility to } \\
\text { Nonresponse }\end{array}$ \\
\hline $04-40$ & $\begin{array}{l}\text { Ron Johnston } \\
\text { Thomas Gschwend } \\
\text { Charles Pattie }\end{array}$ & On Estimates of Split-Ticket Voting: EI and EMax & $04-29$ & Alexander Ludwig & $\begin{array}{l}\text { Improving Tatonnement Methods for Solving } \\
\text { Heterogeneous Agent Models }\end{array}$ \\
\hline 04-39 & Volker Stocké & $\begin{array}{l}\text { Determinants and Consequences of Survey } \\
\text { Respondentsí Social Desirability Beliefs about }\end{array}$ & $04-28$ & $\begin{array}{l}\text { Marc Oliver Rieger } \\
\text { Mei Wang }\end{array}$ & $\begin{array}{l}\text { Cumulative Prospect Theory and the St.Petersburg } \\
\text { Paradox }\end{array}$ \\
\hline $04-38$ & $\begin{array}{l}\text { Siegfried K. Berninghaus } \\
\text { Marion Ott }\end{array}$ & $\begin{array}{l}\text { Racial Attitudes } \\
\text { Restricting the benefit flow from neighbors: } \\
\text { Experiments on network formation }\end{array}$ & $04-27$ & $\begin{array}{l}\text { Michele Bernasconi } \\
\text { Oliver Kirchkamp } \\
\text { Paolo Paruolo }\end{array}$ & $\begin{array}{l}\text { Do fiscal variables affect fiscal expectations? } \\
\text { Experiments with real world and lab data }\end{array}$ \\
\hline & Bodo Vogt & & $04-26$ & $\begin{array}{l}\text { Daniel Schunk } \\
\text { Cornelia Betsch }\end{array}$ & $\begin{array}{l}\text { Explaining heterogeneity in utility functions by } \\
\text { individual differences in preferred decision modes }\end{array}$ \\
\hline $04-37$ & Christopher Koch & $\begin{array}{l}\text { Behavioral Economics und die Unabhängigkeit des } \\
\text { Wirtschaftsprüfers - Ein Forschungsüberblick }\end{array}$ & $04-25$ & $\begin{array}{l}\text { Martin Weber } \\
\text { Jens Wuestemann }\end{array}$ & $\begin{array}{l}\text { Bedeutung des Börsenkurses im Rahmen der } \\
\text { Unternehmensbewertung }\end{array}$ \\
\hline $04-36$ & Christopher Koch & $\begin{array}{l}\text { Behavioral Economics und das } \\
\text { Entscheidungsverhalten des Wirtschaftsprüfers - } \\
\text { Ein Forschungsüberblick }\end{array}$ & $04-24$ & Hannah Hörisch & Does foreign aid delay stabilization \\
\hline $04-35$ & Christina Reifschneider & $\begin{array}{l}\text { Behavioral Law and Economics: Überlegungen zu } \\
\text { den Konsequenzen moderner Rationalitätskonzepte } \\
\text { für die Gestaltung informationellen }\end{array}$ & $04-23$ & $\begin{array}{l}\text { Daniel Schunk } \\
\text { Joachim Winter }\end{array}$ & $\begin{array}{l}\text { The Relationship Between Risk Attitudes and } \\
\text { Heuristics in Search Tasks: A Laboratory } \\
\text { Experiment }\end{array}$ \\
\hline & & Kapitalmarktrechts & $04-22$ & Martin Hellwig & $\begin{array}{l}\text { Risk Aversion in the Small and in the Large When } \\
\text { Outcomes Are Multidimensional }\end{array}$ \\
\hline $04-34$ & $\begin{array}{l}\text { Siegfried K. Berninghaus } \\
\text { Karl-Martin Ehrhart } \\
\text { Marion Ott } \\
\text { Bodo Vogt }\end{array}$ & $\begin{array}{l}\text { Searching for "Stars" - Recent Experimental } \\
\text { Results on Network Formation - }\end{array}$ & $04-21$ & $\begin{array}{l}\text { Oliver Kirchkamp } \\
\text { Eva Poen } \\
\text { J. Philipp Reiß }\end{array}$ & Bidding with Outside Options \\
\hline
\end{tabular}

SONDERFoRSCHUNGsBereich 504 WORKING PAPER SERIES

\begin{tabular}{|c|c|c|}
\hline Nr. & Author & Title \\
\hline $04-20$ & Jens Wüstemann & $\begin{array}{l}\text { Evaluation and Response to Risk in International } \\
\text { Accounting and Audit Systems: Framework and } \\
\text { German Experiences }\end{array}$ \\
\hline $04-19$ & Cornelia Betsch & $\begin{array}{l}\text { Präferenz für Intuition und Deliberation (PID): } \\
\text { Inventar zur Erfassung von affekt- und } \\
\text { kognitionsbasiertem Entscheiden }\end{array}$ \\
\hline $04-18$ & Alexander Zimper & Dominance-Solvable Lattice Games \\
\hline $04-17$ & $\begin{array}{l}\text { Volker Stocké } \\
\text { Birgit Becker }\end{array}$ & $\begin{array}{l}\text { DETERMINANTEN UND KONSEQUENZEN } \\
\text { DER UMFRAGEEINSTELLUNG. } \\
\text { Bewertungsdimensionen unterschiedlicher } \\
\text { Umfragesponsoren und die Antwortbereitschaft der } \\
\text { Befragten }\end{array}$ \\
\hline $04-16$ & $\begin{array}{l}\text { Volker Stocké } \\
\text { Christian Hunkler }\end{array}$ & $\begin{array}{l}\text { Die angemessene Erfassung der Stärke und } \\
\text { Richtung von Anreizen durch soziale Erwünschtheit }\end{array}$ \\
\hline $04-15$ & $\begin{array}{l}\text { Elena Carletti } \\
\text { Vittoria Cerasi } \\
\text { Sonja Daltung }\end{array}$ & $\begin{array}{l}\text { Multiple-bank lending: diversification and } \\
\text { free-riding in monitoring }\end{array}$ \\
\hline $04-14$ & Volker Stocké & $\begin{array}{l}\text { The Interdependence of Determinants for the } \\
\text { Strength and Direction of Social Desirability Bias } \\
\text { in Racial Attitude Surveys }\end{array}$ \\
\hline $04-13$ & $\begin{array}{l}\text { Christopher Koch } \\
\text { Paul Fischbeck }\end{array}$ & $\begin{array}{l}\text { Evaluating Lotteries, Risks, and Risk-mitigation } \\
\text { Programs No A Comparison of China and the } \\
\text { United States }\end{array}$ \\
\hline $04-12$ & $\begin{array}{l}\text { Alexander Ludwig } \\
\text { Torsten Sløk }\end{array}$ & $\begin{array}{l}\text { The relationship between stock prices, house prices } \\
\text { and consumption in OECD countries }\end{array}$ \\
\hline $04-11$ & Jens Wüstemann & Disclosure Regimes and Corporate Governance \\
\hline $04-10$ & $\begin{array}{l}\text { Peter Albrecht } \\
\text { Timo Klett }\end{array}$ & $\begin{array}{l}\text { Referenzpunktbezogene risikoadjustierte } \\
\text { Performancemaße: Theoretische Grundlagen }\end{array}$ \\
\hline 04-09 & Alexander Klos & $\begin{array}{l}\text { The Investment Horizon and Dynamic Asset } \\
\text { Allocation - Some Experimental Evidence }\end{array}$ \\
\hline
\end{tabular}

SONDERFORSCHUNGSBereich 504 WORKING PAPER SERIES

\begin{tabular}{|c|c|c|}
\hline$\overline{\overline{N r} .}$ & Author & Title \\
\hline $04-08$ & $\begin{array}{l}\text { Peter Albrecht } \\
\text { Cemil Kantar } \\
\text { Yanying Xiao }\end{array}$ & $\begin{array}{l}\text { Mean Reversion-Effekte auf dem deutschen } \\
\text { Aktienmarkt: Statistische Analysen der } \\
\text { Entwicklung des DAX-KGV }\end{array}$ \\
\hline 04-07 & Geschäftsstelle & Jahresbericht 2003 \\
\hline 04-06 & Oliver Kirchkamp & $\begin{array}{l}\text { Why are Stabilisations delayed - an experiment } \\
\text { with an application to all pay auctions }\end{array}$ \\
\hline 04-05 & $\begin{array}{l}\text { Karl-Martin Ehrhart } \\
\text { Marion Ott }\end{array}$ & Auctions, Information, and New Technologies \\
\hline 04-04 & Alexander Zimper & $\begin{array}{l}\text { On the Existence of Strategic Solutions for Games } \\
\text { with Security- and Potential Level Players }\end{array}$ \\
\hline $04-03$ & Alexander Zimper & $\begin{array}{l}\text { A Note on the Equivalence of Rationalizability } \\
\text { Concepts in Generalized Nice Games }\end{array}$ \\
\hline 04-02 & Martin Hellwig & $\begin{array}{l}\text { The Provision and Pricing of Excludable Public } \\
\text { Goods: Ramsey-Boiteux Pricing versus Bundling }\end{array}$ \\
\hline 04-01 & $\begin{array}{l}\text { Alexander Klos } \\
\text { Martin Weber }\end{array}$ & $\begin{array}{l}\text { Portfolio Choice in the Presence of Nontradeable } \\
\text { Income: An Experimental Analysis }\end{array}$ \\
\hline 03-39 & $\begin{array}{l}\text { Eric Igou } \\
\text { Herbert Bless }\end{array}$ & $\begin{array}{l}\text { More Thought - More Framing Effects? Framing } \\
\text { Effects As a Function of Elaboration }\end{array}$ \\
\hline $03-38$ & $\begin{array}{l}\text { Siegfried K. Berninghaus } \\
\text { Werner Gueth } \\
\text { Annette Kirstein }\end{array}$ & $\begin{array}{l}\text { Trading Goods versus Sharing Money - An } \\
\text { Experiment Testing Wether Fairness and Efficiency } \\
\text { are Frame Dependent }\end{array}$ \\
\hline 03-37 & $\begin{array}{l}\text { Franz Urban Pappi } \\
\text { Thomas Gschwend }\end{array}$ & $\begin{array}{l}\text { Partei- und Koalitionspräferenzen der Wähler bei } \\
\text { der Bundestagswahl } 1998 \text { und } 2002\end{array}$ \\
\hline $03-36$ & Martin Hellwig & $\begin{array}{l}\text { A Utilitarian Approach to the Provision and Pricing } \\
\text { of Excludable Public Goods }\end{array}$ \\
\hline $03-35$ & Daniel Schunk & $\begin{array}{l}\text { The Pennsylvania Reemployment Bonus } \\
\text { Experiments: How a survival model helps in the } \\
\text { analysis of the data }\end{array}$ \\
\hline
\end{tabular}

